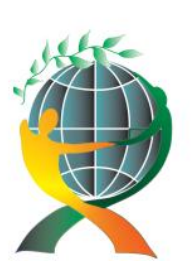

\author{
(online) $=$ ISSN $2285-3642$ \\ ISSN-L = 2285- 3642 \\ Journal of Economic Development, Environment and People \\ Volume 4, Issue 2, 2015
}

URL: http://jedep.spiruharet.ro

e-mail: office jedep@spiruharet.ro

\title{
Opportunities of Establishment of Destination Management and Marketing Organizations in Bulgaria
}

\author{
Ekaterina Arabska ${ }^{1}$, Venelin Terziev ${ }^{2}$ \\ ${ }^{1,2}$ University of Agribusiness and Rural Development
}

\begin{abstract}
The paper examines tourism sector development in the Republic of Bulgaria in the context of the country's strategic priorities till 2020 of knowledge-based economy, sustainable growth and smart specialization, the opportunities for its integration with agri-food sector and potential contribution to balanced rural development. The principles and roles of destination management and marketing organizations are discussed and the opportunities for their application in the national conditions are explored. A framework for of establishment, management and functioning of such organizations is proposed based on integrated and participatory approaches, planning, coordination and communication activities, permanent monitoring and controlling.
\end{abstract}

Keywords: marketing, tourism, rural development, smart specialization

JEL Codes: R10, M39

\section{Introduction}

Challenges before humanity in XXI century connected to climatic changes, insufficiency of resources, pollution of environment, dynamics in international business and uncertainty in economic and political sphere lead to a number of questions regarding sustainable development not only in the sense of "protecting nature for future generations" but also of development of steady in economic, ecological and social relation productions and first of all in internationally oriented knowledge-based economies - a difficult task which in fact includes different elements as: institutional environment for entrepreneurship encouragement, human resources, material and information structure, uniting link in which is the establishment of innovation systems on regional and national levels (Terziev\& Arabska, 2014).

Sustainable rural development is one of the key priorities for future development of Bulgaria considering rural areas with their significant natural, human, economic and cultural potential and contribution to sustainable development. In Bulgaria rural areas are $81 \%$ of the whole territory (National

\footnotetext{
1 E-mail address: katya arabska@abv.bg

${ }^{2}$ E-mail address: terziev@skmat.com
} 


\author{
(online) $=$ ISSN $2285-3642$ \\ ISSN-L = $2285-3642$ \\ Journal of Economic Development, Environment and People \\ Volume 4, Issue 2, 2015 \\ URL: http://jedep.spiruharet.ro \\ e-mail: office jedep@spiruharet.ro
}

strategic rural development plan 2007 - 2013, January 2008) and regional growth is the main target in a number of strategic documents. Sustainable forms of the alternative tourism is one of the key sectors in the processes of diversification of rural economy and it is a leading and a fast growing sector of Bulgarian economy regarding incomes, share in GDP and opportunities of creating employment (Shopova\& Arabska, 2013).

In principle, the development of a sector is influenced by the political system of a country, its socioeconomic environment and the policy framework and tourism policy has been discussed and defined by many authors as a statement of intent of a set course of action agreed upon by public body or agency such as the government or a private organization (Kamble\& Bouchon, 2014).

The analyses of national strategic documents showing state policies and measures for sustainable tourism development conclude that despite the great potential for tourism development in the country the problems prevail and impede sector development outlining the following: predomination of mass seasonable tourism in sea and winter resorts giving the image of the country and the marketing shortcomings in alternative tourism connected to the absence of advertisement and trade marks as well as worsening the quality of tourist services offered, bad infrastructure and overbuilding of mass tourism resorts (Shopova\& Arabska, 2013). The same study points out that tourist organizations have no good interactions and coordination and all year load is very low which has a negative impact on the incomes and sustainability of tourist products as well as on the qualified staff assurance. The following recommendations are given: national resources to be reassessed from the point of sustainable development of agriculture, processing industry and tourism as sectors which could not be developed separately of each other, the most important obstacles for sustainable tourism development to be identified, a national policy for sustainable tourism development to be elaborated based on the integrated approach and embracing all the stakeholders in the tourism sector as well as of other connected sectors. On the other hand, it is concluded that there is a need of diversification in national tourist product and improving the quality of tourist services and tourists' rights and safety assurance; effective marketing campaign of Bulgaria and Bulgarian regions as tourist destinations of alternative type; creating a common system for employment in the sector which will provide all year employment and a quality control of qualifications in the sector; creation of marketing cooperatives / associations / networks in the sector (Shopova\& Arabska, 2013).

Sustainability of tourism (environmental protection and promotion, natural and other resources preservation, cultural values and integrity of local communities) implies extensive cooperation between tourist business and authorities in order to cover a wide group of challenges and at the same time to remain competitive (Angelkova et al., 2012). The competitiveness abilities of tourist destinations in an explicit way show the level of socio-economic development of tourist destination with a special review to quality of life and preservation of natural heritage for future generations (Angelkova et al., 2012).

The potential of tourism development and its socioeconomic and environmental impacts are discussed in a study pointing out some of the indicators of tourism-induced change (Table 1).

In the discussion of competitiveness' issues, it should be noticed that Travel \& Tourism Competitiveness Report 2013 points out Travel \& Tourism competitiveness enablers and change drivers (Fig. 1) among which prioritization of tourism and human resources development are underlined in the current study. 


\author{
(online) $=$ ISSN $2285-3642$ \\ ISSN-L = 2285 - 3642 \\ Journal of Economic Development, Environment and People \\ Volume 4, Issue 2, 2015 \\ URL: http://jedep.spiruharet.ro \\ e-mail: office jedep@spiruharet.ro
}

Table 1. Indicators of tourism-induced changes (Modified by Nepal, 2002)

\begin{tabular}{|c|c|c|}
\hline Tourism as a conservation tool & Tourism as a social catalyst & $\begin{array}{l}\text { Tourism as an income and } \\
\text { employment opportunity }\end{array}$ \\
\hline $\begin{array}{l}\text { Sustainable management of } \\
\text { resources } \\
\text { Environmental improvement } \\
\text { Local awareness about } \\
\text { environmental and social } \\
\text { problems } \\
\text { Biodiversity conservation } \\
\text { efforts } \\
\text { Strengthening local culture and } \\
\text { heritage } \\
\text { Substantial revenues for } \\
\text { government to invest in } \\
\text { conservation and development } \\
\text { Local community development } \\
\text { projects }\end{array}$ & $\begin{array}{l}\text { Upward mobility of those in the } \\
\text { lower social strata } \\
\text { Increased self-reliance, } \\
\text { confidence and motivation for } \\
\text { community development } \\
\text { Increased local participation in } \\
\text { conservation } \\
\text { Participation in planning } \\
\text { processes } \\
\text { Redefinition of local economy } \\
\text { structure }\end{array}$ & $\begin{array}{l}\text { Return of young people to } \\
\text { villages } \\
\text { Local economic benefits, } \\
\text { particularly to strategically } \\
\text { located villages } \\
\text { Some economic benefits to } \\
\text { neighboring regions - spread } \\
\text { effect } \\
\text { Some impacts on other } \\
\text { economic sectors }\end{array}$ \\
\hline
\end{tabular}

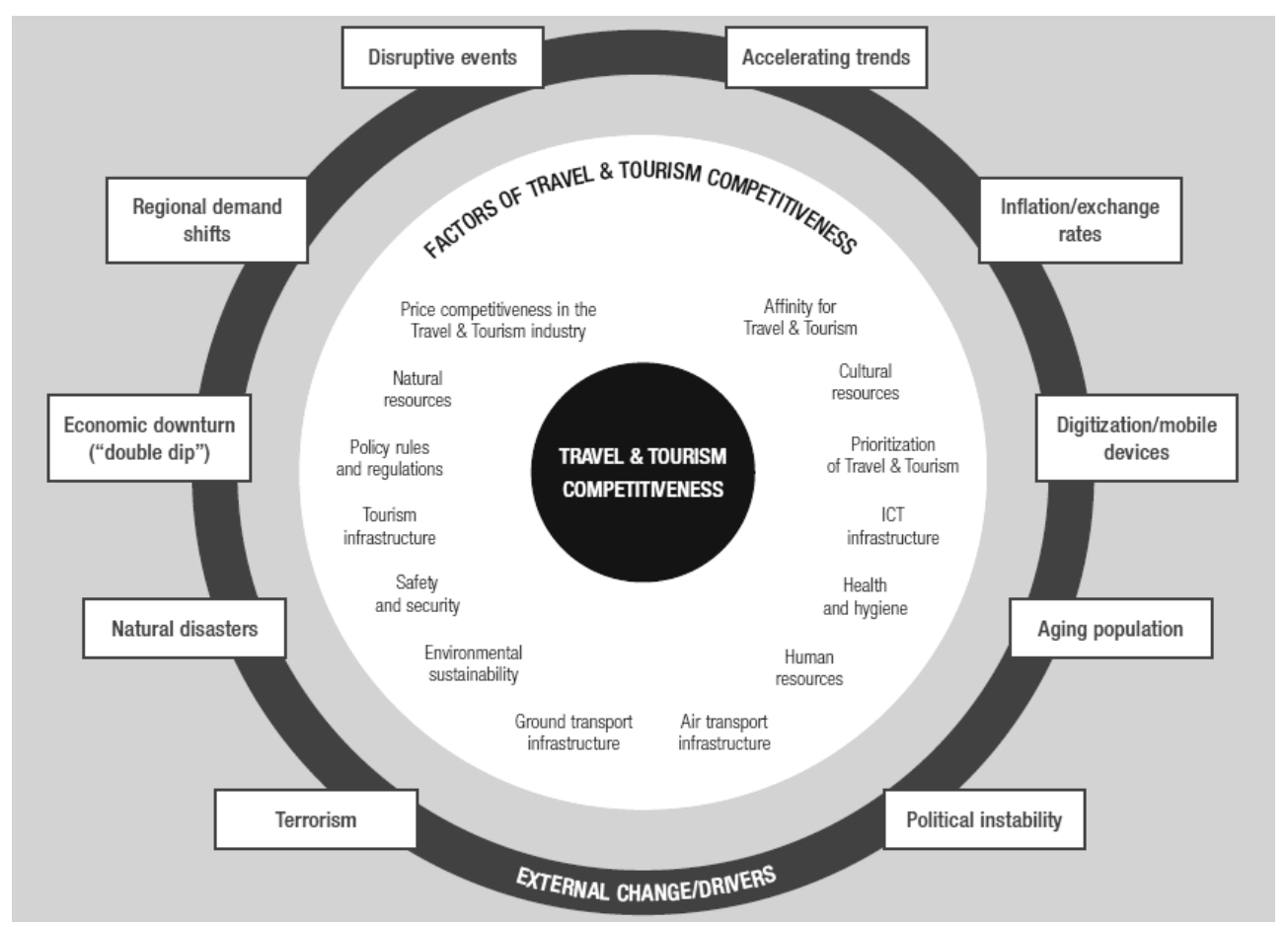

Fig. 1. Travel \& Tourism competitiveness enablers and change drivers (Source: The Travel \& Tourism Competitiveness Report 2013) 


\author{
(online) $=$ ISSN $2285-3642$ \\ ISSN-L = 2285- 3642 \\ Journal of Economic Development, Environment and People \\ Volume 4, Issue 2, 2015 \\ URL: http://jedep.spiruharet.ro \\ e-mail: office jedep@spiruharet.ro
}

Identification of tourism potentials is closely related to the achievement of destination competitiveness on tourism market and future actions should be related to promotion of tourist products within the regions, respect of principles for sustainable development, protection of natural environment, urgency of defined policy, priorities and activities (Nestoroska, 2012).

A study points out that there is a need for the formation of destination management and marketing organisations (DMMOs) in rural tourism destinations and identify its management and marketing roles (Adeyinka-Ojo et al., 2014) summarized as follows: network management organisations, organiser, advocate, catalyst, tourism product developer, community brand builder, convener and facilitator, funding agent, information provider, partner and team builder.

Destination marketing organizations are defined by the Destination Marketing Association International as organizations "charged with representing a specific destination and helping the long-term development of communities through a travel and tourism strategy" regarding the organizations as valuable for visitors, business travelers or planners especially because of the information provided and saved time and energy and they are viewed as "a one-stop shop for local tourism interests". The most important point is the networking opportunities and realities bearing great benefits for all involved.

Destination management and marketing organizations are considered from the context of rural tourism and their roles are concluded for performance in collaboration with rural tourism destination stakeholders in achieving mutual benefits in management of resources, marketing of tourism products, positioning, host community well-being, brand building and tourism loyalty to rural destinations (Adeyinka-Ojo et al., 2014). Roles of destination and marketing organizations could be divided in two groups (Table 2) underlying the framework of such organizations and the need of good management.

Table 2. Roles of destination and marketing organizations (Source: Adeyinka-Ojo et al., 2014)

\begin{tabular}{ll}
\hline Destination management roles & Destination marketing roles \\
\hline $\begin{array}{l}\text { Human resource development } \\
\text { Finance and budgeting management }\end{array}$ & $\begin{array}{l}\text { Destination marketing communication } \\
\text { Safety, security and crisis }\end{array}$ \\
$\begin{array}{l}\text { Destination positioning and branding } \\
\text { Management of tourism assets, attractions } \\
\text { management and sustainability }\end{array}$ \\
$\begin{array}{l}\text { Politics (government, non-governmental } \\
\text { organizations, community relations and } \\
\text { industrial relationships), policy and destination } \\
\text { strategy }\end{array}$ & $\begin{array}{l}\text { Service quality, tourist experience and } \\
\text { customer's relationship management } \\
\text { destination performance management }\end{array}$ \\
\hline
\end{tabular}

On the other hand, the development of the sector is interlinked to development of infrastructure, transport, communications, agri-food sector, etc. Different synergy effects from the interaction of tourism and other local industries are categorized (Holmefjord, 2000): product synergy - local food industries offer tourist products based on existing buildings, competence, etc.; market synergy - marketing effects of 


\author{
(online) $=$ ISSN $2285-3642$ \\ ISSN-L = $2285-3642$ \\ Journal of Economic Development, Environment and People \\ Volume 4, Issue 2, 2015 \\ URL: http://jedep.spiruharet.ro \\ e-mail: office jedep@spiruharet.ro
}

tourists visiting and tasting products, and joint advertising of the place. Tourists are considered as a part of a larger public opinion. The synergy effects to regional resources are underlined too.

The diversification of agricultural producers' activities including agritourism is an opportunity for stabilization of incomes and more. There are numerous benefits from the development of agritourism: it may strengthen local economy, create job opportunities and new businesses; develop and promote training and certification programs to introduce young people to agriculture and environment (Privitera, 2010).

The hard competition on global markets for agricultural produce on one hand and the unattractiveness of rural areas for young people on the other impose the need of seeking for new ways, approaches, technology, products, services, etc. to foster rural development. The process is influenced both by the EU, state and other policies and support and by people's motivation too. (Arabska, 2013). EU policies till 2020 have an accent on organic production as a way of achieving sustainable development.

Organic farming and processing and alternative tourism are key sectors in the rural development and the integrated approach to sustainable rural development through these two sectors will bring economic and social benefits (Arabska, 2014). Organic production is economically effective, ecologically compatible and socially responsible and it occurs to be "an innovative solution for creating entrepreneurial initiatives in rural regions" (Nikolova, 2012) aiming at increase in competitiveness by applying an ecological technology using a new approach - planning, management and control over the production process.

Organic agritourism is a branch with great potentials for development in future in connection to rural development. The evolution of tourists' demand towards nature and its conservation, as well as social and cultural interactions imposes changes on tourist industry in relation to its competitiveness and sustainability. Organic farms offering additional services are a good example in development of sustainable ('green') local tourist products (Arabska, 2014).

The project of the Innovation strategy for intelligent (smart) specialization in the Republic of Bulgaria 2014-2020 from 09.09.2014, being in accordance to the Strategy of smart, sustainable and inclusive growth Europe 2020, puts in the agenda the solution of the problems of sectoral specialization and sustainable economic development. The underlined in its vision "managing social challenges in the fields of demography, sustainable development, intellectual capital and health of the nation" turns into expression through two operational goals embracing innovations in priority thematic fields and innovations for effectiveness of resources and information and communication technology (ICT). In that sense, in their essence as main economic sectors, agriculture and food industry will continue being in the focus of a great number of strategic and program documents in the new period 2014-2020 which is based on the traditional national competitive advantages and image (Terziev\& Arabska, 2014).

The historical development of agricultural sector and the market pressure to provide produce in sufficient quantities at reasonable and acceptable prices lead to the mass application of unsustainable production methods and a as results today many debates are being conducted about ecological and social impacts of agriculture. The trends are that the population on the planet will continue growing in next years, and mostly in urban areas, which means that the food demand will increase too. The establishment of a qualitatively new relation between two opposite parties - urban and rural, is inevitable which will be mutually beneficial, will care of environment and will improve the well-being of both (Terziev\& Arabska, 2014). 


\author{
(online) $=$ ISSN $2285-3642$ \\ ISSN-L = $2285-3642$ \\ Journal of Economic Development, Environment and People \\ Volume 4, Issue 2, 2015 \\ URL: http://jedep.spiruharet.ro \\ e-mail: office jedep@spiruharet.ro
}

Considering that the tourist product is a conventional designation of the complex of tourist services offered at a common price, the product "rural tourism" is about the creation of packages of services, systems of reservation and monitoring targeted to certain groups, and the development of agrotourist market in Bulgaria requires the consolidation of rural tourism objects in a network and a trade marl guaranteeing quality and trust in the establishment of a specific agrotourist product assuring improvement of social and economic conditions in rural regions, diversification of activities in agriculture and high life standard, as well as capacity building and avoidance of rural abandonment (Nikolova et al., 2010).

Responsible tourism is "the most economically, socially and environmentally efficient approach, a real opportunity for exploiting and promoting local products and services" (Petrovici, 2014). Responsible tourism's goals could be formulated as follows: stimulating interest in nature, traditions and communities, respect towards environment minimizing the negative and maximizing the negative impacts (Petrovici, 2014) through harmonization between nature and traditional living environment, unique customs and lifestyle of communities as part of the tourist attractions.

Tourism as a specific and complex industry is too sensitive to recent events of terrorist attacks, economic volatility, weather disasters, new conflict hot spots, etc., leading to changes in tourist demand and focus on new strategies and aspects of operation (Marinoski \& Korunovski, 2012). In the adaptation to this environment, experience shows that the cluster model can be applied to various forms of tourist activities, incl. rural, cultural, mountain, lake and wine tourism (Marinoski \& Korunovski, 2012). Partnerships and networks are a prerequisite for the acceptance of sustainable tourist development if a community and the residents, as part of the economic activity, should be incorporated in the processes of management, communication and advertisement of the region participating in organized and coordinated activities and safeguarding personal and common interests (Bitsani \& Kavoura, 2014). Considering tourism and promotion in the aims of building a positive image and increasing the visibility of tourist destinations, public relations "may represent a bridge towards change, a means for adjusting to the new attitudes triggered by change" (Petrovici, 2014).

The above-described considerations about huge opportunities and great challenges to integrated development of tourism and agri-food sector in rural areas in Bulgaria underline the need of search of new ways and approaches involving stakeholders and local communities and providing support in management and marketing activities in destinations through networking for innovation transfer, capacity building and promotion.

\title{
2. Methodology and data
}

The study reviews the literature discussing roles of destination management and marketing organizations and makes an analysis of the main national strategic documents in the Republic of Bulgaria considering European and national priorities set as establishment of knowledge-based economy and smart specialization for sustainable development. In addition a SWOT-analysis (evaluations of statements in the scale from 1 - the lowest, to 10 - the highest score, which are then averaged) of the opportunities for development of tourism and agri-food sector development in rural regions in the country is made in an experts' focus group. Conclusions are made about the most important roles in establishment and functioning of DMMOs in the country and a framework is proposed. 


\author{
(online) = ISSN $2285-3642$ \\ ISSN-L = 2285-3642 \\ Journal of Economic Development, Environment and People \\ Volume 4, Issue 2, 2015 \\ URL: $\underline{\text { http://jedep.spiruharet.ro }}$ \\ e-mail: office jedep@spiruharet.ro
}

\title{
3. Results and discussion
}

As the leading strategic and program document in the country the National development program Bulgaria 2020 puts the main priorities among which are the achievement of sustainable and integrated regional development and use of local potential and development of the agrarian sector for provision of food security and production with high added value in conditions of sustainable management of natural resources. The opportunities of rural regions to contribute to the priorities and goals are connected to competitiveness of agriculture, attractiveness, networking and risk management, organic farming, qualification, tourism, marketing in tourism, etc. National strategy for sustainable tourism development 2014-2030 (putting special accents on semi-mountain and mountain regions) aims at the durable competitiveness of the country as a tourist destination and contribution to sustainable tourism development and underlines once more the unused potential of mountain regions for rural and ecotourism development and the need of combined tourist products, incl. mountain, pilgrim, cultural, spa and rehabilitation, etc. The project of the Concept for tourism zoning in Bulgaria state that the Tourism law of the country determines the zones as marketing tourist regions which management is connected to activities in three directions: creation of regional tourist products; regional marketing and advertisement; coordination and management of tourism on regional level; creation of tourist zones and organizations for their management - improving marketing, effective use of resources and coordinated activities. The concept provides some proposals about main and extended specialization of tourist zones. The project of the National Innovation strategy for smart specialization also considers tourism and agriculture as traditional sectors, and especially in connection to the good conditions for organic agriculture development.

In some previous analyses of national strategic documents on different levels concerning tourism and agri-food sector development in the country (Arabska, 2013; Shopova\& Arabska, 2013) main conclusions are focused on the need of finding the right ways of implementation of strategic goals. Bearing in mind the opportunities and roles of DMMOs, the opportunities of application of DMMOs according to national conditions are explored through making a SWOT-analysis.

The SWOT-analysis shows very good evaluations for strengths, especially for natural resources, historical and cultural heritage, environmental and climatic conditions (Table 3, Fig. 2). Among the weaknesses training, education and provision of information are underlined which shows the need of new approaches towards capacity building in rural regions. The biggest opportunity is defined to be increasing demand, as well as EU funding opportunities and values and mentality. Financial instability is the greatest threat along with abandonment and replacement processes (Table 3, Fig. 2).

The analysis give insights that the strengths should be properly treated in the use of opportunities and overcoming threats and fighting weaknesses. The need of provision of information and training impose the use of new integrated approaches as networking and common development goals' achievement. An opportunity for that is the establishment of DMMOs in rural regions. 


\author{
(online) $=$ ISSN $2285-3642$ \\ ISSN-L = 2285- 3642 \\ Journal of Economic Development, Environment and People \\ Volume 4, Issue 2, 2015 \\ URL: http://jedep.spiruharet.ro \\ e-mail: office jedep@spiruharet.ro
}

Table 3. SWOT-analysis of the opportunities for development of tourism and agri-food sector development in rural regions through DMMOs

\begin{tabular}{llll}
\hline \multicolumn{1}{c}{ Strengths } & \multicolumn{2}{c}{ Weaknesses } \\
\hline Natural resources & 9.00 & Infrastructure & 4.60 \\
\hline Environmental and climatic conditions & 8.40 & Age structure & 4.40 \\
\hline $\begin{array}{l}\text { Strategies for sustainable } \\
\text { development }\end{array}$ & 7.40 & Living and labor conditions & 5.20 \\
\hline Historical and cultural heritage & 9.00 & Ineffective use of national and EU funding & 4.80 \\
\hline \multicolumn{1}{c}{ Opportunities } & 7.40 & Training and education, information & 6.80 \\
\hline \multicolumn{1}{c}{ Opnal motivation for development } & \multicolumn{2}{c}{ Threats } \\
\hline Local investments & 5.80 & Abandonment / replacement processes & 5.60 \\
\hline SME establishment & 5.00 & $\begin{array}{l}\text { Negative impacts of globalization and } \\
\text { climatic change }\end{array}$ & 4.80 \\
\hline EU funding & 6.20 & Political instability & 5.20 \\
\hline Increasing demand & 6.60 & Financial instability & 6.00 \\
\hline Values and mentality & 6.20 & Communication & 4.40 \\
\hline
\end{tabular}

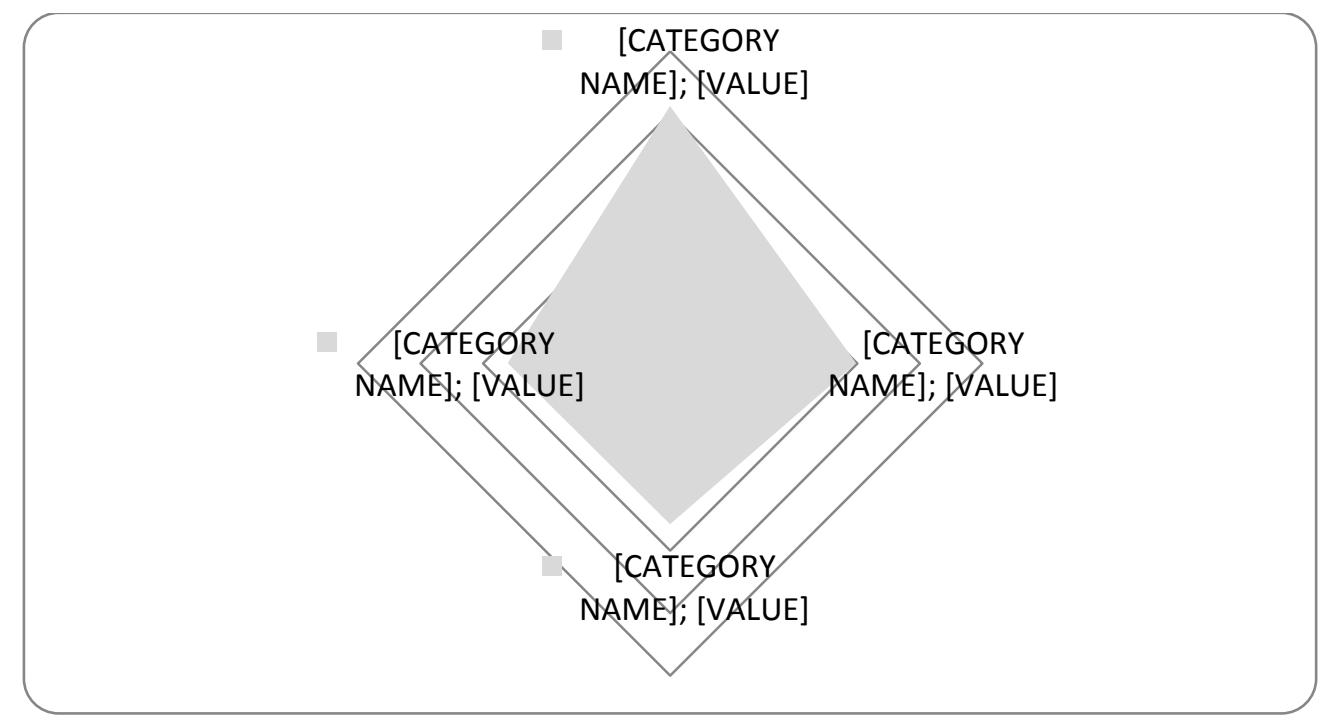

Fig. 2. SWOT-analysis' summarized results

Discussing the role of DMMOs for rural development in the examined country some of the roles are underlined as networking and those connected to development of products and building community brands in rural regions in connection to preparation and management of projects assuring funding (Fig. 3). The vision of country's development is substantiated by the potential of integrated tourism and agriculture activities for overcoming uneven regional development, rural regions' abandonment and low economic growth and assuring sustainable development and well-being of local communities. 


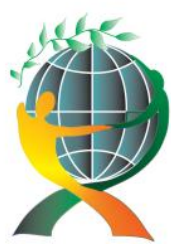

\author{
(online) $=$ ISSN $2285-3642$ \\ ISSN-L = 2285 - 3642 \\ Journal of Economic Development, Environment and People \\ Volume 4, Issue 2, 2015 \\ URL: http://jedep.spiruharet.ro \\ e-mail: office jedep@spiruharet.ro
}

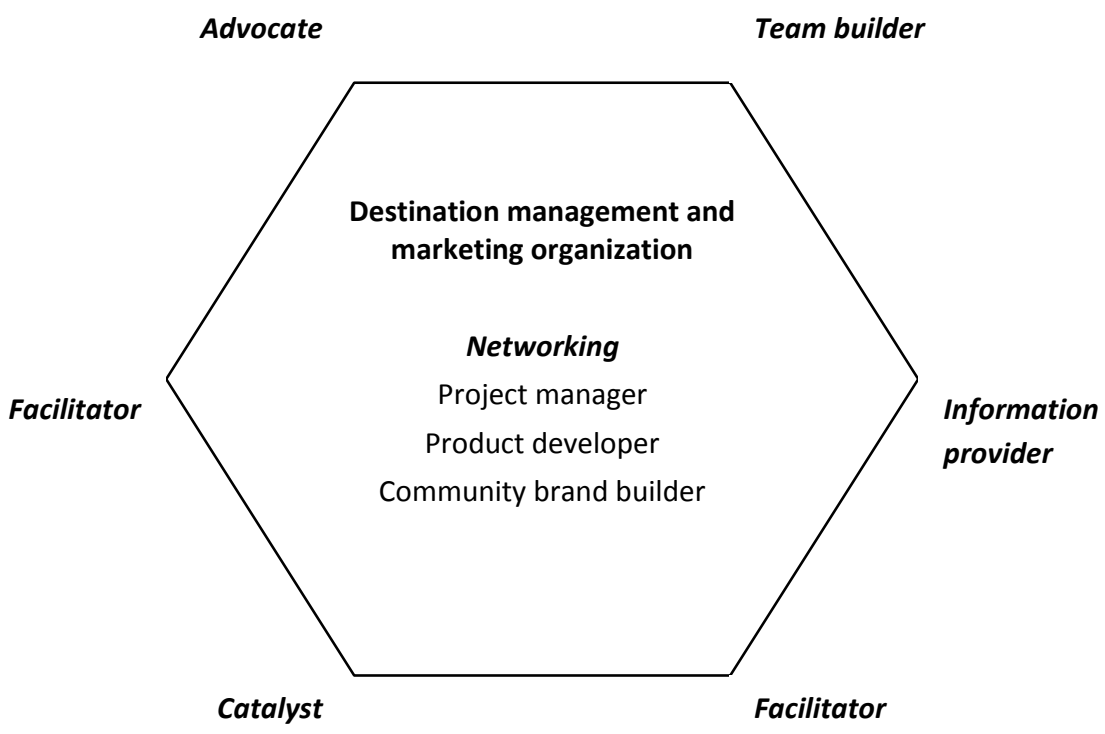

Fig. 3. Framework of the roles of destination management and marketing organizations (Adapted from Adeyinka-Ojo et al., 2014, with modifications)

The framework for establishment, management and functioning of DMMOs as set in the course of the study (Fig. 4) provides the following implications: DMMOs are responsible for network management, management and marketing of destination; stakeholders and local community should be actively involved and motivated through a strategy for inclusion and participation and activities aiming at capacity building. All that would influence destination performance which management should include purposeful activities of planning, organization, implementation, coordination and communication, as well as monitoring and control.

The need of diversification of activities could be answered by the functioning of DMMOs and their contribution to promotion activities, provision of information, capacity building, entrepreneurship encouragement and project implementation, particularly for good practices and innovation transfer.

The establishment of DMMOs is also important because of another point of view - the need of establishment of an effective system of monitoring and control of destination performance in its various aspects and concerning different levels, incl. policies, strategies, programs and plans development, as well as making assessments and recommendations. 


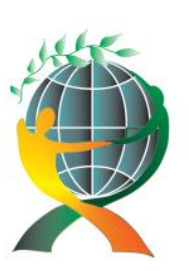

\author{
(online) $=$ ISSN $2285-3642$ \\ ISSN-L = 2285- 3642 \\ Journal of Economic Development, Environment and People \\ Volume 4, Issue 2, 2015
}

URL: http://jedep.spiruharet.ro

e-mail: office jedep@spiruharet.ro

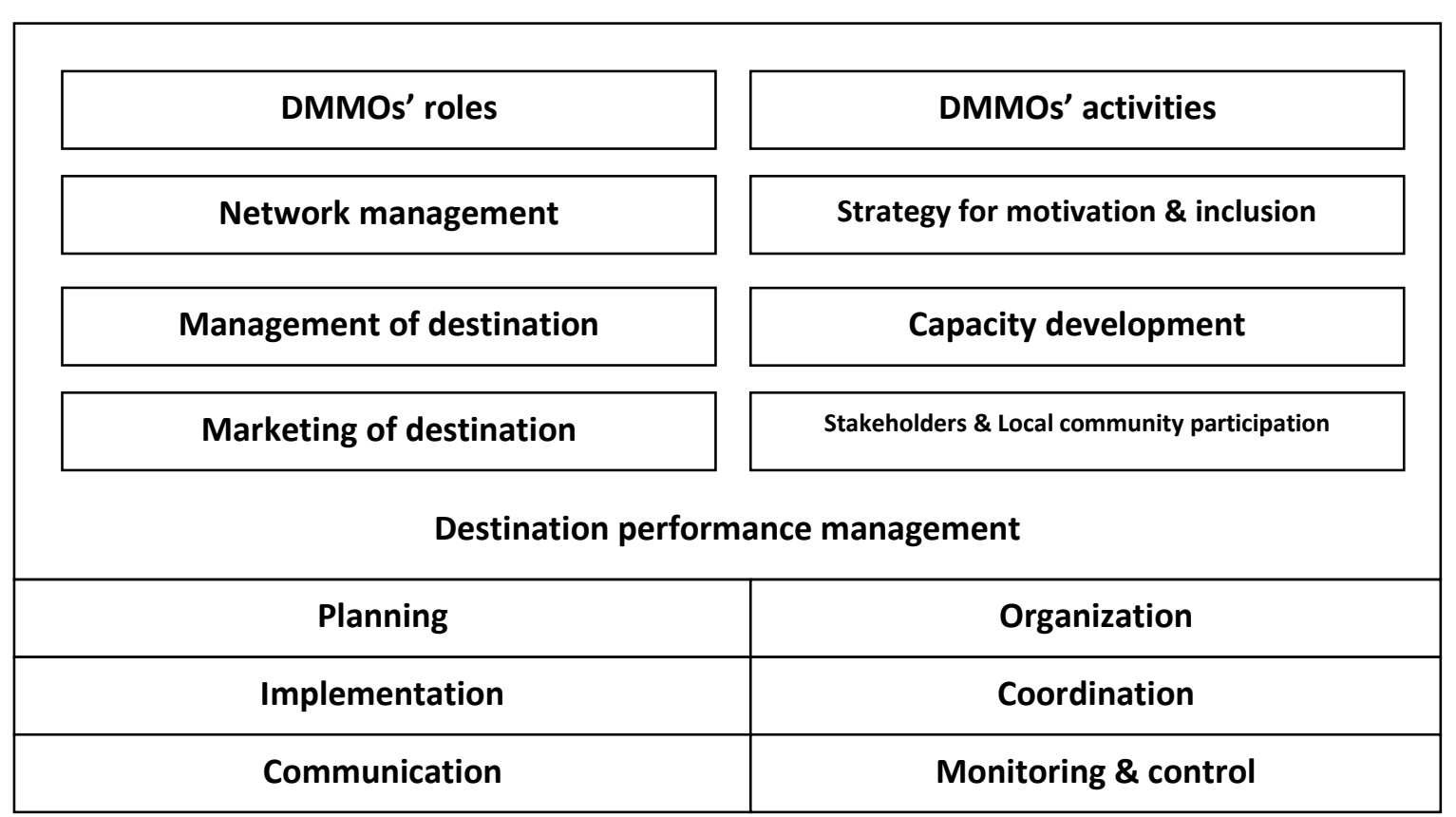

Fig. 4. Framework for of establishment, management and functioning of DMMOs

The joint development of agriculture and tourism should be considered by the need of reducing negative economic, social and environmental impacts on one hand, and on the other of the need of bigger incomes for local population in rural regions. Sustainable growth predisposes the inclusion of local community in planning and decision taking concerning support to economic development, environmental protection and culture and historical heritage conservation. Rural development policies triggered by the fast expanding urbanization processes and rural abandonment should be focused on sustainable / responsible practices in agriculture and tourism development focused on preservation of environment and local communities but also on building confidence in the society as a whole.

\title{
4. Conclusion
}

The strategic priorities for next-year development as given to increase economic, social and territorial cohesion for sustainable balanced regional and municipal development are in regard to the new interrelations and interactions between urban and rural regions based on the use of strengths of both and joint development of mutual benefit through encouragement of sectors having the best potentials in connection to available resources and market realities. The establishment of DMMOs is an opportunity to assure the needed networking and synergy in interactions and activities of the stakeholders and local communities putting the accent on provision of information and rendering assistance in management and marketing of destinations. The study underlines the importance of DMMOs in destination performance management through smart specialization and capacity building. 


\author{
(online) = ISSN $2285-3642$ \\ ISSN-L = $2285-3642$ \\ Journal of Economic Development, Environment and People \\ Volume 4, Issue 2, 2015 \\ URL: $\underline{\text { http://jedep.spiruharet.ro }}$ \\ e-mail: office jedep@spiruharet.ro
}

\title{
5. Acknowledgements
}

The authors would like to thank the experts from University of agribusiness and rural development participating in the focus group making SWOT-analysis evaluations: Ivanka Shopova, Evgenia Velichkova, Nina Ignatova, Kirilka Nenkova and Radostina Stancheva.

\section{References}

[1] Adeyinka-Ojo, S. F., Khoo-Lattimore, C., and Nair, V. 2014. A framework for rural tourism destination management and marketing organisations. Procedia - Social and Behavioral Sciences 144, 151-163.

[2] Angelkova, T., Koteski, C., Jakovlev, Z., and Mitrevska, E. 2012. Sustainability and competitiveness of tourism. Procedia - Social and Behavioral Sciences 44, 221 - 227.

[3] Arabska, E. 2013. Sustainable rural development through organic production encouragement in state and local strategies in Bulgaria.Proceedings of the $4^{\text {th }}$ International Conference of Economic Sciences Quality of Life, Sustainability and Locality; 9-10 May 2013 - Kaposvár University - Kaposvár - Hungary, 518-527.

[4] Arabska, E. 2014. Organic production - innovations and sustainability challenges in development framework and management. Lambert academic publishing, ISBN 978-3-659-56379-9.

[5] Bitsani, E., and Kavoura, A. 2014. Host Perceptions of Rural Tour Marketing to Sustainable Tourism in Central Eastern Europe. The Case Study of Istria, Croatia. Procedia - Social and Behavioral Sciences 148, 362-369.

[6] Concept for tourism zoning in Bulgaria Project, July 2014. Available at: http://strategy.bg. [Accessed: 02/2015].

[7] Destination Marketing Association International web-site: http://www.destinationmarketing.org/faq. [Accessed: 02/2014].

[8] Holmefjord, K. 2000.Linkingproducts, industries and place - synergy effects from the interaction of tourism and other local industries in Lofoten and Hardanger, SNF Project No 6490. Working paper 85/00.

[9] Innovation strategy for intelligent specialization of the Republic of Bulgaria Project. Available at: http://www.mi.government.bg/files/useruploads/files/ris3_09_09_2014.pdf. [Accessed 12.2014].

[10] Kamble, Z., and Bouchon, F. 2014. Tourism planning and a nation's vision: A review of the tourism policy of Sri Lanka. Procedia - Social and Behavioral Sciences 144, 229 - 236.

[11] Marinoski, N., and Korunovski, S. 2012. Tourism in Macedonia in changing environment. Procedia - Social and Behavioral Sciences 44, 19-31.

[12] National development program Bulgaria 2020. Available at: http://strategy.bg. [Accessed: 12/2014].

[13] National strategic rural development plan 2007 - 2013, January 2008. Available at: http://strategy.bg. [Accessed: 12/2014].

[14] National strategy for sustainable tourism development 2014-2030. Available at: http://strategy.bg. [Accessed: 12/2014].

[15] Nepal, S. K. 2002. Tourism as a key to sustainable mountain development: the Nepalese Himalayas in retrospect, Unasylva 208, Vol. 53, 38-46.

[16] Nestoroska,I. 2012. Identifying tourism potentials in Republic of Macedonia through regional approach. Procedia Social and Behavioral Sciences 44, 95-103. 


\author{
(online) $=$ ISSN $2285-3642$ \\ ISSN-L = 2285 - 3642 \\ Journal of Economic Development, Environment and People \\ Volume 4, Issue 2, 2015 \\ URL: http://jedep.spiruharet.ro \\ e-mail: office jedep@spiruharet.ro
}

[17] Nikolova, M. 2012. Organic production in Bulgaria - an innovative solution for creating entrepreneurial initiatives in rural regions. Scientific and applied international conference "Development of agribusiness and rural regions in Bulgaria and EU - perspectives 2020", University of Economics - Varna, 2012.

[18] Nikolova, M., Linkova, M., and Lazarova, E. 2010. Opportunities for formation of the agro-tourist product in Bulgaria. Dialogue E-Journal, issue: 05/2010, 172-189. Available from: www.ceeol.com. [Accessed: 01/2015].

[19] Petrovici, A. 2014. Public Relations in Tourism. A Research on The perception of the Romanian public upon responsible tourism. Procedia - Social and Behavioral Sciences 163, 67-72.

[20] Privitera, D. 2010. The Importance Of Organic Agriculture In Tourism Rural, Applied Studies in Agribusiness and Commerce, Agroinform Publishing House, Budapest, 59-64.

[21] Shopova, I., and Arabska, E. 2013. Sustainable tourism development in rural areas.Proceedings of the $4^{\text {th }}$ International Conference of Economic Sciences; Quality of Life, Sustainability and Locality; 9-10 May 2013 Kaposvár University - Kaposvár - Hungary, 535-546.

[22] Travel \& Tourism Competitiveness Report 2013. Reducing Barriers to Economic Growth and Job Creation. Blanke, J., \& Chiesa, T., editors. World economic forum. Available at: http://www.weforum.org/reports/travel-tourismcompetitiveness-report-2013. [Accessed: 12/2014].

[23] Terziev, V., and Arabska, E. 2014.Inovations in Organic Agriculture for Assuring Food Quality and Safety and

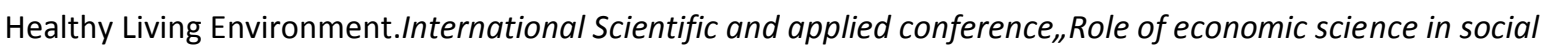
development", UFA-Aeterna, ISBN 978-5-906769-28-2, 3-10. 